Collaboratively Writing a Self: Textual Strategies in Margaret McCord's The Calling of Katie Makanya: A Memoir of South Africa

Author(s): Jenny Siméus

Source: Research in African Literatures, Vol. 46, No. 2 (Summer 2015), pp. 70-84

Published by: Indiana University Press

Stable URL: https://www.jstor.org/stable/10.2979/reseafrilite.46.2.70

JSTOR is a not-for-profit service that helps scholars, researchers, and students discover, use, and build upon a wide range of content in a trusted digital archive. We use information technology and tools to increase productivity and facilitate new forms of scholarship. For more information about JSTOR, please contact support@jstor.org.

Your use of the JSTOR archive indicates your acceptance of the Terms \& Conditions of Use, available at https://about.jstor.org/terms 


\title{
Collaboratively Writing a Self: Textual Strategies in Margaret McCord's The Calling of Katie Makanya: A Memoir of South Africa
}

\author{
JENNY SIMÉUS \\ Linnaeus University \\ jenny.simeus@gmail.com
}

\begin{abstract}
This paper analyzes The Calling of Katie Makanya (1995) by Margaret McCord as a collaborative autobiography. Katie's motive for wanting her story to be told is not a desire to find her own voice and identity through narration, but seemingly rather to add to and complete the picture presented in the narrative My Patients Were Zulus (1946), written by Katie's employer and Margaret McCord's father, Dr. James B. McCord. Moreover, Margaret McCord is portrayed in The Calling of Katie Makanya as finding it problematic as a white woman to write a black woman's story. Using the theories of Judith Butler, the analyses show that the context of the narrative's emergence creates a complex framing of The Calling of Katie Makanya. This paper aims to highlight and examine instances where the effects of this complex framing rise to the surface of the text and create tensions in the narrative.
\end{abstract}

\section{Durban 1954}

Katie sits enthroned on a straight-backed chair in my rented apartment. Her rounded cheeks gleam like polished ebony. Her head is crowned with a velvet cloche, frayed at the seams and pulled down over her ears. Her brown silk dress, probably bought at some church rummage sale, is thirty years out of date, and her leather shoes are scuffed. But her back is straight and she holds her head with regal dignity.

"He mentions me," she taps at the book in her lap. "But you know, Ntombikanina,"-she still calls me by my African name- "there are some things he forgets."

"Different people remember different things," I reply.

She nods. "You are very much educated so you know about these things. That's why you must write my story."

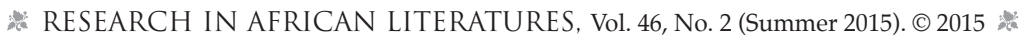




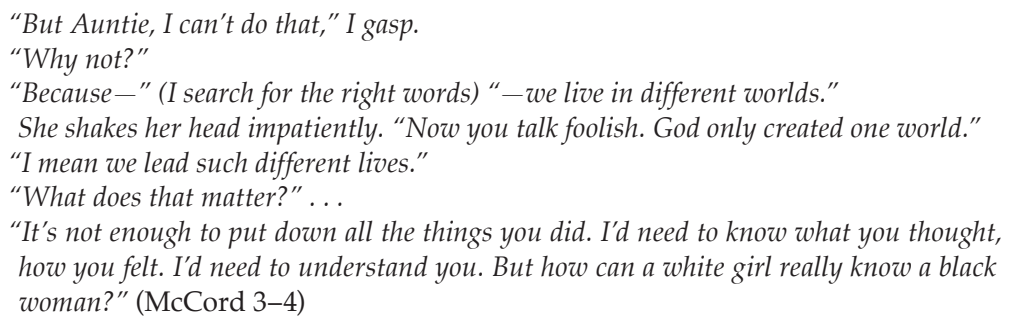

$\mathrm{T}$ hus opens Margaret McCord's book, The Calling of Katie Makanya: A Memoir of South Africa, which was first published in $1995 .{ }^{1}$ The book in Katie's lap is the memoir of Margaret McCord's father, Dr. James McCord, and it is called My Patients Were Zulus (1946). It seems that one of Katie's reasons for wanting to have a book written about her life was to fill in some of the blanks Dr. McCord left. ${ }^{2}$ James McCord was an American doctor who was working in South Africa during the late 1800 s and the first half of the 1900s. Katie Makanya was an interpreter and nurse that Margaret McCord's father worked with and she took care of Margaret McCord when she was young. Katie Makanya later asked Margaret McCord to help her write her life story. In 1954, Margaret McCord interviewed Katie Makanya and wrote The Calling of Katie Makanya based on the tape recordings of these interviews.

One of the first things that might catch a reader's eye is that as The Calling of Katie Makanya was first published in 1995, some forty years passed between Margaret McCord's last meeting with Katie Makanya in 1954 and the publication of the book. ${ }^{3}$ Moreover, the structure of the book is complex in the sense that there are two separate storylines on-going in the text. One of the storylines is told in the first person by Margaret, where she describes the meetings and interviews with Katie in Durban. There is also one short passage at the very end of the book labeled "California 1993," where Margaret is looking back on their last meeting and reveals that Katie died only some months later. ${ }^{4}$ These passages in italics sometimes comment on what was just told on the previous pages and work as a bridge to the continuation of the storyline. The main storyline, on the other hand, is told by an omniscient anonymous third-person narrator and contains the actual narrative about Katie and her life from 1873 to 1954.

There is also a preface where Margaret McCord addresses potential questions regarding the writing process and to what extent the book is "told in her [Katie's] own words, and how much I [McCord] may have embellished it" (vii). Due to how the text is structured, it is not entirely easy to determine whether The Calling of Katie Makanya should be read as a novel or as a collaborative autobiography or as some form of mixture between the two. Indeed, Thengani H. Ngwenya's article "Ideology and Self-Representation in Autobiography: The Case of Katie Makanya" describes it as "Margaret McCord's understanding of Katie Makanya's fascinating life" (154). For the purpose of this paper, I have opted to treat the text as a form of collaborative autobiography, albeit one where the subject had very little to no influence on the final form of the published narrative (seeing as Katie died shortly after the interviews were conducted). Despite her death before the completion of the book, I do not think that it would do the narrative justice to treat it as a biography since Katie Makanya explicitly wished for her narrative to participate 
in the same literary conversation that Dr. McCord's autobiography did. Moreover, Katie Makanya asked Margaret McCord for help to write her story down; not for McCord to write it without Katie's own involvement. The passages in italics where Margaret McCord has inserted her own views and memories of the collaborative process further emphasize the collaborative nature of the project.

Indeed, as G. Thomas Couser writes in Vulnerable Subjects-Ethics and Life Writing, one of the common denominators for most collaborative life writing is that "one member supplies the 'life' while the other provides the 'writing'" (36). Couser further makes the important point that while the term "collaborative" might imply that a text is written cooperatively, this is not always the case, even though the process might be cooperative-something that certainly applies to The Calling of Katie Makanya. In his chapter "Collaborative Autobiography," in Encyclopedia of Life Writing: Autobiographical and Biographical Forms, Couser discusses collaborative autobiography in terms of a continuum that ranges from "ethnographic autobiography, in which the writer outranks the generally anonymous subject, to celebrity autobiography, in which the famous subject outranks the generally anonymous writer" (222). I have elsewhere elaborated on this continuum by adding a vertical line that crosses Couser's continuum in order to better illustrate the amount of influence collaborative autobiographical subjects and writers may or may not have over the process. This way, one can better consider the collaborative writing process both in terms of the social status of subject and writer and in terms of the amount of influence the subject and writer respectively have over the writing process. Collaborative autobiography is, thus, usually a form that exists in-between biography and the traditional autobiography, which Philippe Lejeune famously has defined as a "[r]etrospective prose narrative written by a real person concerning his own existence, where the focus is his individual life, in particular the story of his personality" (4). As Sidonie Smith and Julia Watson point out in Reading Autobiography: A Guide for Interpreting Life Narratives, it is "the terms of the collaboration" that are of particular interest when reading collaborative life-writing works (240). In the case of the collaboration between Katie Makanya and Margaret McCord, McCord obviously made all final decisions on the form of the narrative. However, it was Makanya who, from the very beginning, had a clear image of both what she wanted her narrative to contain and of what discourse she wanted her narrative to be a part, namely that of Dr. McCord's autobiographical narrative.

As for her own role within the narrative, in an interview with Stephen Meyer published in 2000, Margaret McCord said that "what I wrote about myself was really (except perhaps for the epilogue) to explain reactions of Katie or the relation with Katie" (247). Meyer himself makes the following observations in connection to the issue of Margaret McCord's involvement in the narrative and in the collaborative process:

Since David Stoll's Rigoberta Menchú and the Story of All Poor Guatemalans ... and Arturo Arias' The Rigoberta Menchú Controversy ...., the problematics of texts like The Calling of Katie Makanya have once again been brought to public attention. Two of the issues at stake are the nature of the truth of the claims raised in such publications and the notion of the subject, which touches on issues like authorship and appropriation. The former issue has been central to the Rigoberta Menchú debate and the latter to criticisms of Joubert's Poppie.... 
I have tried, both here and elsewhere, to frame these issues in a different light. I suggest that most of these criticisms directed at collaborative auto/biography are still indebted to a monological philosophy of consciousness and would need to be reformulated if they are to hit the mark. They disregard the extent to which, as Habermas argues, truth and identity are intersubjectively generated in speech and acts of reciprocal recognition, a fact borne out by the production and reading of The Calling of Katie Makanya. $(237)^{5}$

However, while the text The Calling of Katie Makanya could, as Meyer argues, be considered an example of the dialogical nature of truth and identity and an example of how these two concepts are created through interaction between people, this argument disregards two important issues that I will delve into deeper in this paper. Firstly, that a major reason that Katie wants her life story written down is the memoir by Dr. James McCord; a narrative that I will show is steeped in a colonial discourse and that, to a large extent, marginalizes Katie. She is, thus, seemingly driven by a desire to "write back" as it were; to set straight the things that doctor McCord "forgets" in his narrative rather than a desire to find her own voice and identity through narration (McCord 3). Secondly, in the primary text, Margaret is portrayed as finding it problematic for her as a white woman to write a black woman's story, thus aiming the very same criticism at her own writing project that Meyer argues is missing the mark. This creates a complex framing of the text and I intend to examine instances where the effects of this rise to the surface of the text and create tensions in the narrative.

The Calling of Katie Makanya is not the first or only South African-collaborative autobiography. As discussed above, there was roughly a forty-year gap between Margaret's interviews with Katie and the publication of the finished text. In-between these two events, collaborative autobiographical texts such as Peter Lanham and A. S. Mopeli-Paulus's Blanket Boy's Moon (1953) and Elsa Joubert's Die Swerfjare van Poppie Nongena (1978) were published. As Meyer points out, it is not uncommon for the reviews of and scholarly articles on collaborative autobiographies of this kind to focus on the issues of truth and appropriation. ${ }^{6}$ While these issues may seem important to clear out, I concur with Meyer's Habermas-inspired point of view that, in collaborative autobiography, the textual selves are generated through the collaboration or, in Meyer's words, "generated in speech and acts of reciprocal recognition" (237). But how does this happen?

Considering that the result of McCord and Makanya's collaboration was not published until 1995, the discussions and criticism surrounding other similar publications, perhaps most notably South African author Elsa Joubert's The Long Journey of Poppie Nongena (1980), which was first published in Afrikaans as Die Swerfjare van Poppie Nongena (1978), likely affected McCord in the process of writing. ${ }^{7}$ Margaret McCord's awareness that there could be potential criticism aimed at her as a white woman writing a black woman's story probably resulted in a conscious effort to preemptively deflect it by writing herself into the story. Thereby, rather than keeping the collaborative process invisible in the narrative, like Douglas and Dr. McCord did, Margaret McCord turned the spotlight onto her own involvement and made it part of the narrative. While Katie insists that the difference between herself and Margaret lies only in their skills (in this case, writing skills), Margaret argues that there is some form of fundamental difference 
between them, stemming from the "different worlds" in which they live, according to her. Margaret is the one who sees a potential problem with her writing Katie's story - they have different skin colors and, by extension, in a South African social context, especially at the time of the interviews with Katie Makanya in the 1950s, this means that they live in different (social) worlds. In an interview from 2002 published in Selves in Question, Margaret McCord remarked on the issue of her being a white woman writing a black woman's story:

I knew from my experience in the United States that the American blacks would say, "A white woman wrote that story, it doesn't mean anything." I was not just any white woman growing up in Africa who felt she could "explain" the African problem, and I didn't want to write about the "African problem." So I tried first of all, to get across the fact that Katie did indeed insist that I write the story, secondly, that my relationship with her was different from that of most young white women growing up in this country, and finally, by inserting my own recollections now and then, I hoped to keep in the reader's mind that this was a true story and not fiction. (Coullie et al. 211, emphasis added)

As this quote shows, Margaret McCord was concerned both about criticism regarding the issue of the truth of the narrative, as well as potential criticism of the legitimacy of the narrative, as exemplified by the issue of social inequality between Margaret McCord and Katie Makanya in terms of a white woman writing a black woman's story. Can one use the tools of an oppressive society, such as its language, to write about or discuss the conditions of the oppressed in that same society in such a way that one does not simply perpetuate that oppression through one's use of that very same discourse? This is an issue that many scholars have discussed and not only in a South African context. American writer and activist Audre Lorde has argued that "the master's tools will never dismantle the master's house" (112). She originally made this observation when she noticed the lack of black feminists at a conference aiming to discuss topics of "difference within the lives of american [sic] women" and asked herself what it means when "the tools of a racist patriarchy are used to examine the fruits of that same patriarchy" (110-11). While Lorde's observation was made in a context different from the one in which The Calling of Katie Makanya was written, it is helpful in illuminating Margaret's initial concerns about collaborating with Katie and writing the book together. Moreover, having lived and worked in the United States for many years, Margaret McCord was likely aware of this American context and debate. In fact, what Lorde is saying is that you cannot achieve anything other than temporary change if you attempt to critically examine a phenomenon using the same ideas (tools) of which this phenomenon has been the source. It is this that Margaret McCord was conscious of and that clearly affected how she chose to structure the narrative in The Calling of Katie Makanya, making it part of that narrative's emergence.

Continuing on the issue of the emergence of the narrative, it has already been established that The Calling of Katie Makanya emerged from an act of dialogue between the life subject (Katie Makanya) and the writer (Margaret McCord). The textual version of Katie is one of the results of this process. Indeed, as John Paul Eakin emphasizes in Living Autobiographically. How Our Lives Become Stories, there is "an extremely close and dynamic relationship between narrative and identity, for narrative is not only a literary form but part of the fabric of our lived experiences" 
(2). In order to better comprehend the process of the narrative's emergence in relation to The Calling of Katie Makanya, I will turn to Judith Butler. In Giving an Account of Oneself, Butler observes that the act of telling a story to somebody by necessity involves an act of transference. Butler reaches this conclusion by drawing on psychoanalysis, a field that, according to Butler, "has always understood this dual dimension of the self-disclosing speech act" (50). She draws on scholars of psychoanalysis such as Roy Schafer, who are of the opinion that creating a coherent self-narrative is one of the goals of psychoanalysis as a way to become familiar with oneself through an act of narrative reconstruction that is assisted by an analyst or therapist. When one gives an account of oneself, this is not only an attempt to convey information about oneself, but it simultaneously "recreates and constitutes anew the tacit presumptions about communication and relationality that structure the mode of address" (Ibid.). In this context, Butler defines transference as "the recreation of a primary relationality within the analytic space, one that potentially yields a new or altered relationship (and capacity for relationality) on the basis of analytic work" (50-51, emphasis added). Drawing on these insights from psychoanalysis, Butler concludes that self-narration by definition includes an act of transference:

"I" tell a story to "you," and we might together consider the details of the story that I tell. But if I tell them to you in the context of a transference (and can there be telling without transference?), I am doing something with this telling, acting on you in some way. And this telling is also doing something to me, acting on me, in ways I may well not understand as I go. (51)

While Butler draws on psychoanalysis when discussing narration and transference, the conclusions are still relevant in the context of collaborative autobiography and the emergence of a collaborative narrative. When applied here, transference captures how the act of narrating one's life to somebody else is not a one-way action. There are always at least two people engaged in an act of telling and writing of some sort and this means that not only will the text be affected by the collaboration in the sense that it will contain more than one autobiographical voice, but the collaboration will also have an effect on the people involved in the storytelling.

Moreover, Butler concludes that a narrated subject always is created by more than one person, since language is a social construction and the act of giving an account of oneself by definition always involves an other; someone to whom the account is addressed. This interaction between addresser and addressee is, as the quote above implies, not a one-way interaction. I find that Butler's approach to selfnarration is more inclusive and wide compared to a more text-centered approach. Bearing Butler's observations in mind, it becomes interesting to take a closer look at the beginning of the The Calling of Katie Makanya. The introductory chapter about how the collaboration came about ends with Katie positioned as the traditional black mother telling stories to children, as Margaret's nine-year-old son Johnny comes home from school and asks to hear Katie tell a story:

\footnotetext{
"... You wanted to hear about my old ancestor?"

"Yes." She waits until he adds quickly, "Please."

"It was a long, long time ago."

"How long?"
} 


\begin{abstract}
"When I was four or five. Half as old as you are now. That must have been-" (she pauses, counting on her fingers) "-in 1878. I was standing with my sister Charlotte by the wagon tracks in front of our house."

Lulled by the cadence of her voice, I lean back against the sofa, listening to a story I have heard so many times I can almost repeat it word for word. I close my eyes and the years drop away. I am a child again. ... (4)
\end{abstract}

Katie is telling a story and her voice telling the story is also acting on Margaret. On a physical level, the rhythm of Katie's voice is lulling Margaret, making her feel relaxed. On a psychological level, the story that Katie is telling takes Margaret back to her childhood, effectively turning her into "a child again" (Ibid.). Seeing as this is the end of the opening section of the text, it also sets the tone for the framing of the entire text and positions Katie as an old black woman telling stories to the younger generation. Katie seems much like her grandmother, who, in the opening pages, is telling Katie stories about "those terrible Zulus" (7). ${ }^{8}$ As illustrated by the quote above, the meeting between the two collaborators takes place on multiple levels: there is a physical meeting between them outside and there is a meeting within between the textual representations of the writers (re)created in the text. This means that the transference takes place on multiple levels as well: both inside and outside of the text. This transference comes full circle at the end of Katie's narrative, where she tells her great granddaughter that she is her old ancestor who will tell her a story after dinner.

I want to continue by looking at how Katie is (re)created in the text by Margaret McCord. Returning to the opening quote of this paper, it seems that Katie immediately is positioned by the narrator (Margaret) as an African queen. Margaret likens the gleam of Katie's cheeks to that of ebony and her head is held with "regal dignity." Katie refers to Margaret as Ntombikanina, something that is explained by Margaret to be her own African name. This opening paragraph firmly delineates what kind of characters Katie and Margaret are in the text and what their roles will be. Katie, who was capable of reading and writing herself, defers to Margaret's higher level of education and seems to have unwavering faith that this by default provides Margaret with a better toolkit than her own to write down her story. "Western education," especially British education received overseas, is positioned as being important throughout the The Calling of Katie Makanya and not only by Katie. For instance, to explain how important education is, Katie's and Charlotte's father tells a story about how he had to deliver a box of figs and a paper, noting how many figs were in the box. He covered the paper with a stone so that it could not see him eating some of the figs and he was convinced that the paper with writing was magic because it could still tell the store owner just how many figs he had eaten. After hearing the story, Katie laughs at what she thinks of as the foolishness of her father, whereas her sister Charlotte finds their father's previous illiteracy anything but amusing: "'Some day we'll go there to teach them,' she said. 'I'll go beyond this place, beyond Port Elizabeth, beyond the sea. I'll go to England to study what the white people are taught. Then I'll come back to teach our people'" (11). Thus, it is not surprising that Katie expresses such a strong desire to have Margaret help her put her story into words.

Paradoxically, the portrayal of Katie in the text is that of a Christian person believing in "one world," as she refers to it, and she does not hesitate to correct 
Margaret and even goes so far as to call her foolish when she claims she cannot write Katie's story as they live in different worlds. Yet, the way Katie speaks of the whites in the text and the way Katie is speaking of the writing project imply that for her, the educated whites and the way they view the world is the right way as opposed to the way the uneducated Zulu patients see it. As a contrast, when Katie and her sister Charlotte traveled to England with a choir in 1891, she encountered a different attitude from white people toward African culture. This encounter is shown to greatly impact her and, thus, by extension, it has an impact on her collaborative autobiographical narrative as well.

The description of Katie and the choir arriving in London touches on many points that commonly are found in texts containing this trope of "the Other" visiting a European city for the first time. ${ }^{9}$ There is the realization that, in England, being white does not automatically mean you are well-off or that it grants you social status:

Katie had heard so much about the wonderful things she would see in London
that she was not surprised by the trains running along the tops of houses or the
great buildings with roads underneath them or the double-decker horse-drawn
buses lumbering down the streets. But when she stepped down from the train
at the railway station she was amazed to see white men carrying heavy trunks
on their backs.
"Look, Charlotte, these Englishmen are their own kaffirs," she giggled. For the
first time in her life she used the word "kaffir" with malicious glee. At home the
Europeans called the black people kaffirs. (32)

However, it soon becomes clear to Katie that the fact that even though some white people might be carrying her things in London, this did not mean that she was considered to be on equal footing with the whites. The Calling of Katie Makanya contains sixteen photographs portraying different people and places connected to Katie's life and two of them are of the choir during its visit to England. The choir looks very different in these two pictures in terms of clothing. In one, they are wearing Victorian clothing, much like people were dressed in London at the time, with the women wearing gowns and the men in suit jackets. In the other picture, the entire choir is dressed up in what the caption describes as "tribal dress"; they are wearing ostrich feathers, beadwork, skins from leopards, and a tiger skin with its head still attached to it is spread out on the floor in front of the choir. ${ }^{10}$ As Veit Erlmann correctly observes in his chapter on the England visit of this choir in the book Africans on Stage: Studies in Ethnological Show Business, rather than having anything to do with how Africans really dressed at the time, these clothes and animal skins were what signified Africa to the English audience. At the start of the performance the choir was dressed in this "tribal dress" and halfway through they changed into Victorian dress. Erlmann concludes the following about the reason for this change of clothes:

[T] he whole point about the "native" dress was precisely to illustrate how much Victorian models of "universal history" and the chorister's own personal history coincided, thanks to the "civilizing mission." The change from native dress to Victorian clothing in the two parts of the performance was to be a serious demonstration in progress of the progressive history of their wearers. (128) 
The "tribal dress" was, thus, not at all representative of what the choir would wear at home, but rather worked as a means to display what the Londoners expected Africans to look like. The manner in which the choir members were treated as a spectacle rather than as people and performers in their own right caused Katie to decline the choir manager Mr. Vert's offer for her to return to England as a solo singer later on:

\begin{abstract}
Mr Vert looked at her as though she were an ignorant child. "I don't think you understand. I'll make you rich and famous - so rich you will be able to buy anything you want, go anywhere. You'll sing in the great concert halls of Europe, and even kings and queens will pay you homage."

Katie laughed. "A black girl like me? Whoever heard of such a thing?"

"They will," he promised. "When they hear your voice, they won't wonder who you are or where you come from. They won't see you. They'll just listen to you sing."

Katie's laughter stopped abruptly. She thought of the children in London pointing their fingers and calling out, "Come look at the darkies." . . . She thought of a white South African whose words had echoed across the dining-room in a big hotel, "They may look civilised in their Christian clothes, but underneath, the blacks are all savages." At least those people had seen her. . . .

"I don't sing for people who do not see me," she said abruptly. (56-57)
\end{abstract}

The last line of this quote is the key to understanding how Katie's self is constructed in the text. Katie is telling her story in relation to the discourse in which Dr. McCord's text aims to participate; a discourse in which she is invisible. Reading The Calling of Katie Makanya next to the book that motivated Katie to write her own story, Dr. James McCord's book, My Patients Were Zulus (1946), reveals just how invisible Katie is in his narrative, even when the spotlight is on her.

Dr. McCord's text is a straightforward first-person autobiographical narrative, told from his perspective and mainly focusing on his years as a doctor in South Africa between 1899 and 1940. Present already in the opening passage of The Calling of Katie Makanya, Dr. McCord and his book play an important role also in Katie's text. The title itself, My Patients Were Zulus, is interesting, as Katie strongly resents being considered an African in the ethnic sense of the word used to describe the choir during their visit to England. She is portrayed as wanting to be seen as a person, not only as an African or as a Zulu (which Katie was not, as she was a Fingo) dressed up in African-stereotype apparel. On the front cover, James B. McCord and John Scott Douglas are listed as the authors, with Douglas as the copyright holder of the text. Thus, My Patients Were Zulus is also a type of collaborative autobiographical text. The difference between Katie's text and Dr. McCord's text is mainly that there is no trace of collaboration in the latter, other than in the listed authors. This means that My Patients Were Zulus manifests as a classic autobiography while in fact being some form of collaborative autobiography. The line between autobiography and collaborative autobiography is, thus, somewhat blurred in Dr. McCord's text and the collaborating writers play very differing roles in the two texts. The narratives do converge on a few points and reading those passages side by side reveals some interesting differences. The example below recounts the point where Katie was asked to work for the doctor and their first meeting. Dr. McCord's summary is quite brief: 
[F]inding a general female assistant and interpreter for the consulting and examination room was ... difficult. After I had talked to several girls, Mr. Kilbon recommended Katie Makanya, then working for a British family about to leave South Africa. Katie came and looked around my consulting room with an almost proprietary air, then smiled at me with such good humor that I found myself smiling back. Both of us realized from that moment that the subsequent interview was needless formality; I was as determined to keep her as she was to stay. (McCord and Douglas 59-60)

Katie's description of this meeting differs from that of Dr. McCord and it is quite a lengthy passage to quote. However, it is important to include most of it in order to properly illuminate the difference between Katie's and the doctor's texts and thereby get to the core of this analysis; the different textual strategies used when negotiating how one writes one's self in the two texts. This is how the first meeting is described in Katie's narrative:

One Wednesday morning in 1902 Katie walked along the road toward the mission, feeling at peace with herself. ... A few patients were already sitting about on the grass behind the dispensary when she got there.... Suddenly a boom of laughter thundered out which shook the house and made the door frame rattle. Katie gasped.... Then, as suddenly as it came, the laughter was finished. The house stopped shaking and ... the door to the room swung wide open. $\mathrm{Mr}$ Kilbon and Mr Bunker stepped out of the shadow into the sunlight, and she saw them both quite distinctly. But the third man remained behind, a ghostly presence in the dim light. His massive shoulders filled the doorway, his head almost touching the top of the frame... Then the ghost stepped into the sunlight. So convinced was she that Mbambo's spirit had come to find her that she did not comprehend what she saw-a man with skin the colour of ocean sand and eyes of pale blue fire....

The ghost was calling out to her. "Umgqibelo tells me you're my new interpreter." But he was no ghost. He was the new doctor. She knew this by the long white coat worn over his shirt and trousers.

"Yes, sir. No, sir," she muttered.

"What's that? Speak up."

"Yes, sir. I'm Katie.... And no, sir, you'll have to find another interpreter."

"But I thought it was all arranged...."

"No, it was not arranged. . . Just for this morning I'll help you," she said. "But tomorrow you will have to hire someone else."

"Then come along." He started striding up a path. Katie had to run to keep up with him. (152-53)

At one point a bit further on, Katie almost faints when the doctor cuts open an abscess and she is required to look at it. It turns out she has no experience with the kind of work the doctor expects of her outside of her interpretation duties. However, at the end of this first day, she agrees to come back the day after and continue her work and her training.

These two versions of this first meeting are quite different. Dr. McCord's brief paragraph describes what almost comes across as an account of a first meeting between two soul mates; an instant feeling of belonging, the two of them smiling at one another and knowing without needing to use any words that they both want to work with each other. Dr. McCord even goes so far as to claim to 
know what Katie was thinking, as he wrote that "[b]oth of us realized from that moment that the subsequent interview was a needless formality" (60, emphasis added). This passage becomes a very clear illustration of the white man's interpretative prerogative. Katie's description, on the other hand, contains no such notions. Moreover, while Dr. McCord is a central part of Katie's narrative, Katie plays a very marginal role in his narrative, as can be literally discerned through the amount of space in the text that has been devoted to their first encounter. The same observations can be made about other convergent points in the two narratives, such as Dr. McCord curing Katie's sister Mary Ann Makanya from her severe case of syphilis and reconstructing Mary Ann's nose. ${ }^{11}$ In general, incidents or information about Katie that are brought up in Dr. McCord's book are expanded on greatly in Katie's narrative.

What is interesting about reading these two narratives side by side like this is that it is possible to trace many of the threads from Katie's narrative directly back to those of Dr. McCord. In order to better understand this connection and (albeit one-way) communication between the two texts, I once more want to turn to Judith Butler. Drawing on thinkers such as Adorno, Butler argues that " $[\mathrm{w}] \mathrm{hen}$ the ' $\mathrm{I}$ ' seeks to give an account of itself, it can start with itself, but it will find that this self is already implicated in a social temporality that exceeds its own capacities for narration" (7-8). Thus, Butler posits that in attempting to give an account of oneself, the account of the "I" must, by default, "include the conditions of its own emergence" (8). Returning to Katie's and Dr. McCord's narratives, while bearing Butler's observations in mind, it becomes clear that the connection between the two texts, where Katie has expressed a desire to complement or add to Dr. McCord's narrative, also exists on a discursive level. Dr. McCord's text aims to become a part of and conform to the norms of the discourse of traditional autobiography and, in so doing, it is indirectly connected to all those previous narratives within that discourse. Katie's narrative is similar to that of Dr. McCord's in that content-wise it covers her life from her early years growing up until the narrative's present in 1954.

However, Katie's narrative ends up being quite different from the traditional straightforward narrative of Dr. McCord, as is indicated in the opening quote of this paper where Margaret initially objects to taking on the task of writing Katie's story and says, "It is not enough to put down all the things you did. I'd need to know what you thought, how you felt. I'd need to understand you. But how can a white girl really know a black woman?" (4). In these two lines lie the clue to the conditions of this narrative's emergence; a different tradition and what could be called a different autobiographical discourse. In this discourse, the phenomenon of one person writing another person's story is not an unproblematic task to carry out; especially not when the two parties come from different cultures or differ greatly in terms of social status.

Let us return for a moment to Makanya's aspiration for her story to be written with the master's tools. This aspiration meant that she wanted her story to be written in English. In this sense, language also becomes one of the master's tools and the choice of language is instrumental in order to create a narrative that participates in the same tradition of writing as Dr. McCord's narrative. Margaret McCord brings up the issue of language in one of the passages in italics: 


\section{Durban 1954}

Katie seems tired this morning. She leans more heavily on my arm as she climbs the steps to my front door. I wonder if she is strong enough to continue our daily sessions. Yesterday, when she had recalled Mbambo's final journey to Umgeni, her eyes had filled with tears and she had lapsed into Zulu as though she had forgotten my presence.

"Auntie," I say gently when she is settled in her chair, "you know that I grew up in town and never learned to speak Zulu properly."

"I know," she says, and her eyes flash with remembered exasperation. "I tried to teach you but you were always too impatient."

"Then do you realise that sometimes, instead of speaking English, you lapse into Zulu or Sotho, depending on whom or what you're talking about?"

"If I do that, you should interrupt and ask me what I'm saying."

I shake my head. "When I was a child, you taught me it was rude to interrupt."

She laughs. "I won't scold you any more."

But it's not the fear of scolding that will stop me. It's the fear of interrupting her train of thought. As she picks up the microphone, I know that on occasion I will have to replay the tape to the Zulu and Sotho nurses in my father's hospital and rely on them to translate the words I do not know. (141)

The words Margaret McCord has chosen to describe Katie Makanya's shifts into speaking Zulu or Sotho instead of English are quite important. McCord defines the language shift as a lapse into Zulu or Sotho, indirectly implying (however unintentionally) that this occurrence is something undesirable and inconvenient that happened when Katie became very emotional and her subconscious took over. Katie, on the other hand, seems very set on telling her life story in English rather than in an African language. She even asks Margaret to interrupt her storytelling if she is speaking Zulu or Sotho instead of English. Margaret McCord herself was not fluent in Zulu although she could make herself understood and would be able to understand most of it when spoken. McCord's solution to this language problem was to let some nurses at the hospital in Durban perform the translations. In the aforementioned interview with Stephen Meyer, she describes the nurses and their translation work:

The nurses, being high school graduates, wanted to be very exact and they also wanted to show off their knowledge of English. So they would come over and dictate their translation of what she said, and it would come out in rather flat high school English. Then my problem was to rephrase it so that it fit into Katie's way of speaking. Sometimes I succeeded and sometimes I didn't, but at least I made the effort to keep the poetic quality of the Zulu language in the story and that was a conscious effort. (245)

A professional translator was, thus, seemingly never engaged in the project and the nurses' translations were rephrased by Margaret McCord before they were included in the text. This means that, at times, what Katie Makanya said was mediated by multiple people before being put into writing. By default, this convoluted translation process ought to also have affected the textual selves portrayed in the book, but this is not further problematized or discussed by Margaret McCord.

In conclusion, my reading of The Calling of Katie Makanya has highlighted the complex framing of the narrative and the tensions in the text that this complex framing creates. By claiming a subject position for herself in a text that aims to 
show a different perspective on or act as a complement to Dr. McCord's narrative, Katie Makanya's narrative poses an important question to its readers about who is allowed to write their life story and make themselves the subject of an autobiographical text.

\section{NOTES}

1. For the sake of clarity, I will refer to Margaret McCord and Katie Makanya with their names and surnames or only surnames, when I refer to them in their functions as authors and creators of the text, and as Margaret and Katie when referring to them as characters within the text.

2. See, for example, the interview with Margaret McCord in Coullie et al. 206.

3. When interviewed and asked about the time difference between the recording of Katie Makanya's story and its publication in book form, Margaret McCord answered, "Well, I was married. I had two children to raise" (Meyer 246). However, in personal emails to researcher Vanessa Anne Farr, Margaret McCord reveals that the delay was due to not being able to find a publisher for the text since, in the American publishers' view, "the market had been saturated with stories about Africa" (109-10).

4. I have written elsewhere about the imbalance in power between writer and subject in the process of writing a collaborative autobiography in relation to South African author Zoë Wicomb's novel David's Story (2001). This novel deals with the creation of a collaborative autobiography that is completed by an unnamed amanuensis after the death of its subject, David. See also Couser, "Collaborative."

5. Nobel Peace Prize winner Rigoberta Menchú is a Guatemalan political activist who wrote a testimonial autobiography entitled I, Rigoberta Menchú (1984). Much controversy arose regarding whether Menchú had told the truth in her autobiography and she was accused of having changed details of her life story.

6. See, for example, Anne Mager's and Peter Merrington's reviews of The Calling of Katie Makanya.

7. See Dalven, Lenta, McClintock, and Penvenne for some of the debate concerning Joubert as a white educated woman writing Poppie's story and the fictionalization of Poppie. However, it is important to bear in mind that Katie Makanya in 1954 was in a different social situation than Poppie in the 1970s. Katie Makanya was not just anybody; she traveled overseas, she had a hospital wing named after her, and she was viewed as a kind of authority figure within the field of nursing, whereas Poppie was an anonymous black woman with much less social status.

8. The Zulus fought and conquered many other African peoples during the 19th century, creating the Zulu kingdom that dominated much of what today makes up KwaZulu-Natal. Katie Makanya's family are Fingoes, descendants of the Mba people who were driven off their land by the Zulus. See Davenport $66 \mathrm{ff}$.

9. See, for example, McLeod and Ball.

10. The tiger skin is particularly intriguing as there are no tigers native to Africa.

11. Mary Ann is referred to as Marian in Dr. McCord's text.

\section{WORKS CITED}

Ball, John Clement. Imagining London: Postcolonial Fiction and the Transnational Metropolis. Toronto: U of Toronto P, 2004. Print.

Butler, Judith. Giving an Account of Oneself. New York: Fordham UP, 2005. Print.

Coullie, Judith Lütge, Stephan Meyer, Thengani H. Ngwenya, and Thomas Olver, eds. Selves in Question. Interviews on Southern African Auto/Biography. Honolulu: U of Hawai'i P, 2006. Print. 
Couser, G. Thomas. "Collaborative Autobiography." Encyclopedia of Life Writing: Autobiographical and Biographical Forms. Vol 1. Ed. Margaret Jolly. London: Fitzroy Dearborn, 2001. 222-23. Print.

- Vulnerable Subjects: Ethics and Life Writing. Ithaca: Cornell UP, 2004. Print.

Dalven, Kristi. “Native Witness, White 'Translator': The Problematics of Tran/Scribing in Elsa Joubert's Poppie Nongena." Violence, Silence, and Anger: Women's Writing as Transgression. Ed. Deirdre Lashgari. Charlottesville: UP of Virginia, 1995. 80-91. Print.

Davenport, Rodney, and Christopher Saunders. South Africa-A Modern History. 5th ed. London: Macmillan Press Ltd., 2000. Print.

Eakin, John Paul. Living Autobiographically: How We Create Identity in Narrative. Ithaca: Cornell UP, 2008. Print.

Erlmann, Veit. "'Spectorial Lust': The African Choir in England, 1891-1893.” Africans on Stage: Studies in Ethnological Show Business. Ed. Bernth Lindfors. Bloomington: Indiana UP, 1999. 107-34. Print.

Farr, Vanessa A. "'A Chanting Foreign and Familiar': The Production and Publishing of Women's Collective Life Writing in South Africa." Diss. York University, 2002. Print.

Joubert, Elsa. Die swerfjare van Poppie Nongena. 1978. Cape Town: Tafelberg Publishers, 1986. Print.

—. The Long Journey of Poppie Nongena. 1980. Cape Town: Tafelberg Publishers, 2000. Print.

Lanham, Peter, and A. S. Mopeli-Paulus. Blanket Boy's Moon. London: Collins ClearType Press, 1953. Print.

Lejeune, Philippe. On Autobiography. 1975. Trans. Katherine Leary. Minneapolis: U of Minnesota P, 1989. Print.

Lenta, Margaret. “Goodbye Lena, Goodbye Poppie: Post-Apartheid Black Women's Writing." Ariel: A Review of International English Literature 29.4 (1998): 101-18. Print.

Lorde, Audre. Sister Outsider. 1984. New York: Crossing Press, 2007. Print.

Mager, Anne. Rev. of The Calling of Katie Makanya, by Margaret McCord. South African History Journal 34 (1996): 299-302. Print.

McClintock, Anne. "'The Very House of Difference': Race, Gender and the Politics of South African Women's Narrative in Poppie Nongena." Social Text 25-26 (1990): 196-226. Print.

McCord, James B., and John Scott Douglas. My Patients Were Zulus. 1946. New York: Rinehart \& Company, Inc, 1951. Print.

McCord, Margaret. The Calling of Katie Makanya: A Memoir of South Africa. New York: John Wiley \& Sons, Inc, 1995. Print.

McLeod, John. Postcolonial London: Rewriting the Metropolis. London: Routledge, 2004. Print.

Menchú, Rigoberta. I, Rigoberta Menchú: An Indian Woman in Guatemala. Trans. Ann Wright. London: Verso, 1984. Print.

Merrington, Peter. Rev. of The Calling of Katie Makanya, by Margaret McCord. Kronos: Journal of Cape History 22 (1995): 155-57. Print.

Meyer, Stephan. "Collaborative Auto/Biography: Notes on an Interview with Margaret McCord on The Calling of Katie Makanya: A Memoir of South Africa." Oral Tradition 15.2 (2000): 230-54. Print. 
Morgan, Jonathan, and the Great African Spider Writers. Finding Mr Madini. Claremont: Ink, 1999. Print.

Ngwenya, Thengani H. "Ideology and Self-Representation in Autobiography: The Case of Katie Makanya." Missions of Interdependence: A Literary Directory. Ed. Gerhard Stilz. Amsterdam: Rodopi, 2002. 143-55. Print.

Penvenne, Jeanne. "Elsa Joubert's Poppie Nongena." African Novels in the Classroom. Ed. M. J. Hay. Boulder: Lynne Rienner Publishers, Inc., 2000. 153-66. Print.

Reyher, Rebecca Hourwich. Zulu Woman: The Life Story of Christina Sibiya. 1948. New York: Feminist Press at the City University of New York, 1999. Print.

Siméus, Jenny. "Complex Collaborations: Elsa Joubert's The Long Journey of Poppie Nongena and Zoë Wicomb's David's Story." Ariel: A Review of International English Literature 45.1-2 (2014): 221-45. Print.

Smith, Sidonie, and Julia Watson. Reading Autobiography: A Guide for Interpreting Life Narratives. 2nd ed. Minneapolis: U of Minnesota P, 2010. Print.

Wicomb, Zoë. David's Story. New York: Feminist Press at the City University of New York, 2001. Print. 